\title{
Language, residential space and inequality in Cape Town: Broad-brush profiles and trends
}

\author{
Lloyd Hill\$ and Simon Bekker \\ Department of Sociology and Social Anthropology \\ University of Stellenbosch, Email: lloydhill@sun.ac.za, Tel: +27-21-808 2096, Fax: +27-21-808 2143
}

\begin{abstract}
This article uses South African census data for 1996, 2001 and 2011 to explore the relationship between language and demographic change in the metropolitan region of Cape Town. We begin with a conceptual and methodological discussion of the use of 'language' as a demographic variable, before commencing with a GISbased analysis of the changing relationship between 'household language' and selected census variables associated with post-apartheid demographic change. We focus particular attention on variables selected to shed light on urban inequality, such as education level, income, race and in-migration. Data on adults at ward level in Cape Town is used to develop a comparative spatial context for this analysis. Our main finding is a significant level of continuity between 1996 and 2011 with respect to the geo-social patterning of the three main languages in the metro: Afrikaans, English and isiXhosa. We argue that English and Afrikaans have retained status through proximity to key development corridors. We explain this trend in terms of different streams of migrants, settling at different times and in different regions of the city.
\end{abstract}

Keywords: language; migration; urbanisation; Cape Town; South Africa

\section{Résumé}

Cet article utilise les données des recensements de l'Afrique du Sud en 1996, 200 l et 201I. Nous explorons la relation entre les langues sud-africaines et l'évolution démographique dans la région métropolitaine du Cap (Cape Town). Nous commençons par une discussion conceptuelle et méthodologique de l'utilisation de "langue» comme une variable démographique, avant de commencer avec une analyse, basée sur le SIG, de l'évolution de la relation entre «langue des ménage» et les variables de recensement liés aux changements démographiques post-apartheid. Nous nous concentrons en particulier sur les variables sélectionnées pour éclaircir les inégalités urbaines, indiqués par le niveau d'éducation, le revenu, la race et l'immigration. Les données sur les adultes au niveau de la paroisse (ward) du Cap sont utilisées pour développer un contexte spatial comparatif pour cette analyse. Nous observons un niveau significatif de continuité entre 1996 et 201 I par rapport à la répartition géo-sociale des trois langues principales dans le métro: afrikaans, anglais et xhosa. Nous expliquons cette tendance en termes de différents groupes de migrants qui se sont installés à différents moments et dans différentes régions de la ville.

Mots-clés: langue; migration; urbanisation; Le Cap; Afrique du Sud

\footnotetext{
\$Corresponding Author 


\section{Introduction}

Cape Town is a port city situated at the confluence of the Southern Atlantic and Indian Oceans. It has over the past three centuries played a pivotal role in conquest, in trade and in the passage by sea of Europeans, of Asians and of Africans. As its reputation grew, it also attracted Africans from its hinterlands in increasing numbers. It is no surprise, accordingly, that these residents, during different periods of Cape Town's growth, spoke different languages in their various communities: Dutch, Khoi and Melayu in earlier periods; the subsequent emergence of Afrikaans; English after 1806; and the in-migration of isiXhosa speakers (Bickford-Smith 1995, Dubow 2006, Giliomee 2003, Keegan 1996, Worden et al. 1998). Today, three languages dominate the cityscape of Cape Town: Afrikaans, English and isiXhosa.

Over the past half century, South African cities and Cape Town in particular - have been discussed by urbanists within a widely shared and well-defined context. The 'apartheid' city had emerged and it was characterized by racial segregation - applied spatially to residential areas - and was associated with high degrees of inequality, and with influx control, which restricted the flow of Africans into urban areas. Once apartheid was abolished, cities were tasked both to address the inequalities inherited from this recent past as well as to facilitate the integration of racially segregated residential areas. To these ends, single tier metropolitan authorities with a single tax base have been established in eight cities (Oldfield 2004, Smith 1992, Watson 2002, Wilkinson 2000).

In debates on whether progress has been made, urbanists have focused on two divides within the city: the racial divide in urban space and secondly, the divide between the elite and affluent residents, on the one hand, and the working and underclasses, typically fragmented, on the other (Bekker \& Leildé 2006, Leildé 2008). An early assessment of whether progress was being made in Cape Town concluded that 'racial segregation has been replaced by social segregation, in effect by "deracialised apartheid" (Saff 1998). But to what extent is racial segregation being replaced by class segregation?

Our aim in this article is to explore the relationship between language and these divides in Cape Town. More specifically, this relationship will be explored spatially by identifying language patterns at ward level in the metropolitan region ('metro') in $20 \mathrm{II}$ and by comparing this spatial profile to that of
$200 \mathrm{I}$ and of 1996. Subsequently, a number of case studies will be selected - based on shared language features in the wards that make up each case. The class and racial profiles of adults in these cases, as well as trends over the fifteen year inter-census period, will then be explored. Finally, we look at the influence that in-migration has had on the demography of these areas. In our final analysis we explore - in broad-brush - the extent to which class and racial divisions within Cape Town's residential space have changed and, secondly, the extent to which language correlates with inequalities associated with class and race in Cape Town.

\section{Preliminary reflections on 'language' as a census variable}

In the censuses of 1996, 200I and 20II questions on language refer to speech (speaking) in the context of a "home" (1996) or a "household" (200I and 20I I). But while the 1996 and $200 \mathrm{I}$ censuses refer in the singular to the "language" spoken most often at home, the 201I questionnaire asks "which two languages does (name) speak most often in this household?" In 201 I respondents therefore had the opportunity to indicate two languages spoken in the household and about $52 \%$ of the national population did in fact indicate a second household or home language. In the metadata that accompanied the release of the $201 \mathrm{I}$ census statistics these variables are labelled "first language" and "second language." In the analysis presented below we prefer the term 'main household language' to cover responses to the 1996 and 200I questions, as well as the first coded response to the 201I question.' We offer two reasons for this decision.

Firstly, the terms 'first language' and 'second language' have specific meanings in the growing literature on 'second language acquisition' (wherein first and second language are commonly abbreviated as LI and L2). In this literature, particular attention has been given to the educational status of English and issues associated with the learning and use of English as a second language (Boughey, 1998; Granville et al, 1998; Setati et al, 2002). The census variables reflect nominal associations between members of a household and the eleven official languages. These official categories do not - as Donnelly (2003) notes - provide a good indication of the actual spoken repertoires of individual respondents. Issues relating to language acquisition and language competence fall beyond the scope of this study; they are only relevant to our initial 
exploration of the meaning of the census variables covering 'language.' In terms of this conceptual delimitation, our use of the term 'household language' assumes a basic level of competence in the specified official language. Our concern to minimise the risks associated with this assumption - and to bracket as far as possible issues associated with early language acquisition and intra-family language shift constitutes the first reason for restricting the study population (as discussed below) to people aged 20 years or more.

The second reason for our adoption of the term 'household language' has to do with the manner in which the census variables on 'language' should be interpreted (for 1996, 200 I and - most importantly - 20II). Given the lack of ordinality in the 20II census question ii, two issues of interpretation arise. The first concerns the meanings attributed to the two language categories and the second concerns the extent to which the sequencing of the responses was interpreted by respondents as ordinal. With respect to meaning, the census question does not distinguish between 'first language' in the more common psycholinguistic sense (used in acquisition research, as discussed above) and an alternative (and more sociological) sense of 'common language', i.e. the language that is used most commonly in the household.ii We argue that, given the phrasing of the $201 \mathrm{I}$ census question, this latter interpretation makes more sense, and this is the interpretation that informs our use of the term 'household language' in the analysis that follows. The term 'household language' is also useful as it suggests a context-bound competence: the census focus on languages spoken "in this household" privileges the home domain at the expense of other domains (most notably work). Assuming equivalent translations into the other official languages, 'language' should therefore be understood to mean "most common household language", rather than "first language learned" (or the language in which the respondent is most competent). The distinction is moot in households where only one language is spoken, but relevant for the approximately $52 \%$ of South African respondents and $71 \%$ of Western Cape respondents who indicated two household languages." ${ }^{i v}$ The distinction is therefore particularly relevant in the context of the Western Cape, where a number of studies have noted patterns associated with an inter-generational shift from Afrikaans to English (Anthonissen, 2013; Farmer, 2008).
'Household language', in this sense, therefore underpins our use of the term "language shift" in the subsequent analysis. Here "shift" denotes a "geographical shift", or a change in the number of respondents - within a household, ward or other territorial unit - who have reported using an official language as the main means of household communication. Census data can therefore provide an ancillary indication of language change at the level of the household, but they do not provide a good basis for inferring trends associated with "language shift" in the more common sociolinguistic sense of the term.

To the extent that we are interested in 'common languages' that are also official or institutionalized 'standard languages', we need to acknowledge the normative commitment inherent in our use of census language categories (and other official categories as well, but notably race ${ }^{\text {) }}$. The census language categories reflect the post-1994 Constitutional commitment to eleven official languages. Our use of these categories therefore reflects a normative orientation: a general recognition of these eleven standardized forms of language, even as we acknowledge and seek to understand the complexities that underlie these norms. Moreover, a particular interest in educational inequality (as one aspect of wider social inequality) underpins our attempts to explore the relationship between the official language categories and other indicators of urban inequality. Education is the policy domain in which debate about the institutionalization and development of the official languages has been particularly acute.

\section{Additional conceptual and methodological considerations}

This study focuses on the City of Cape Town, which is one of eight "Category A" or metropolitan municipalities in South Africa. In this section the focus falls on two constitutive aspects of the study: the definition of the study populations and the decision to focus on wards as the basis for GIS analysis. In addition to a discussion of the methodology used to produce the maps and statistical data presented in subsequent chapters, we provide a brief summary of population trends in the city as a whole.

This study draws on South African census data for 1996, 200I and 201I. For all three years the census datasets comprise individual level data, which 
were collected by means of the Household Questionnaire. The study populations that form the basis of this research consist of all Cape Town residents aged 20 years or more when each of the three censuses were conducted. For the three census years the adult population, so defined, constituted about two thirds of the total populations. The total population grew from 2565 018 in 1996 to 2893251 in 2001 and 3723043 in 2011 - revealing an acceleration in total metro population from $2.6 \%$ per annum during the first inter-census period to $3 \%$ pa during the second.

Our decision to define an adult population in this way reflects, in the first instance, our conceptualization of 'household language', as outlined above. Secondly, we use level of education (along with income) as a rough proxy for class inequality, and in doing so we follow a convention used by Statistics South Africa (subsequently referred to as 'Stats SA') for working with educational data, in terms of which 20 is considered to be a more stable age than 18 , and hence a more appropriate age on which to base comparisons of educational attainment. ${ }^{\mathrm{vi}}$

GIS-analysis and the subsequent production of maps was done using the ArcGIS Desktop 10 software. While much of the statistical analysis was conducted by the authors using Stats SA's SuperCROSS census software, the decision to use electoral wards as the basis for the spatial representation of the data presented a number of challenges. Principal among these was the need to produce standardized GIS-referenced datasets for the three census years, based on the 201I ward boundaries. ${ }^{\text {vi }}$ The reason for this is that ward boundaries change over time and these changes indirectly reflect the impact of the previous census. The delimitation of wards is subject to the determination of the number of councillors in a municipal authority - in this case the City of Cape Town. In terms of the municipal electoral system, $50 \%$ of councillors are elected according to proportional representation, while the remaining $50 \%$ are elected to represent wards. Any change in the overall allocation of councillors therefore has a direct effect on the delimitation of wards (Craythorne, 2003: 59).

Our decision to use wards as the basis for exploring the spatial distribution of languages is motivated in terms of a number of the criteria that guide delimitation. Firstly, wards have a communal property to the extent that one of the criteria for demarcation is "the need to avoid as far as possible the fragmentation of communities" (Craythorne, 2003: 6I). Cameron (2010: 8) - citing international trends - notes that while, in principle, the "subjective views of the community" is a factor in demarcation (particularly where demarcation becomes overtly politicised), in practice local authorities tend to do little more than solicit opinions. Wards are therefore political constructs and can in no obvious sense be considered to reflect specific communal identities. Secondly, wards and their associated ward committees are constructed in terms of the norms associated with participatory democracy in local government. Our analysis in turn reflects a qualified commitment to these norms qualified in terms of the theoretical assertion that there can be no neutral or objective depiction of language. The eleven official languages are examples of what Bourdieu (1991: 37) calls "legitimate languages", which are not simply 'competences' acquired by individuals; they are also enduring constructions, established through their (unequal) historical association with objects (e.g. print and electronic media), places and institutions.

In 201 I the City of Cape Town comprised III wards with an average population of $3354 I$ people per ward. In our study population the average adult population was 22463 per ward, with a population range of 13415 to $3830 \mathrm{I}$. Our analysis proceeds in two stages. We begin by focusing on the census statistics for the three languages that predominate in Cape Town: Afrikaans, English and isiXhosa. ${ }^{\text {viii }}$ These three languages are used to produce ward-based profiles of Cape Town for 1996, 200I and 20II. Drawing on patterns of language continuity and change (between 1996 and 201 I), we analyse trends evident in these profiles and use these as the basis for a more focused study of the relationship between language and inequality in seven submetropolitan case studies in the metro. The case study areas comprise wards that are generally contiguous and that share one or more of the language criteria identified in the initial stage of the analysis. The second stage of the analysis therefore takes the form of a cross-tabulation (using 20 II data in SuperCROSS) of the seven ward-based cases and three sets of census variables: race ('population group'), class and in-migration. ${ }^{\text {ix }}$ Two census variables - individual monthly income ${ }^{x}$ and level of education - are used together to serve as an approximation of social class in the adult 
populations. We conclude with an exploratory discussion of the influence language appears to be having on the changing class and racial divides within these seven sub-metropolitan case study areas.

\section{Language and residential space in Cape Town: themes and case studies}

The 2011 census reported that some 2570749 adults (aged 20 or above) resided in Cape Town. Of these, 36\% were Afrikaans-speakers, 29\% Englishspeakers, $28 \%$ isiXhosa-speakers and the remainder - some $6 \%$ - indicated other languages as their preferred language at home ${ }^{\mathrm{xi}}$. This remainder was approximately equally divided between adults reporting other official South African languages and those reporting foreign languages.

These proportions have not remained static within the adult population over the last fifteen years, as the different annualised rates of increase in the different language categories imply:

- the number of Afrikaans speakers has been increasing the slowest - with an annualized increase over this period of approximately $1.5 \%$.

- the English speaking population revealed a low rate of increase in the late 1990s with a significantly increased rate during the next decade - annualized change from 2 to $3.1 \%$.

- the number of adult isiXhosa speakers increased at a very high rate during the late 1990s and a significantly lower one during the next decade - annualized change from 8.5 to
$3.4 \%$ - this latter rate however still remains the highest of all adult language groups in the intercensus decade of $200 \mathrm{I}-20 \mathrm{II}$.

- in the two remaining categories - encompassing other official South African languages and foreign languages - the numbers are small, but have nonetheless increased significantly over this fifteen year period - each from rates of less than $1 \%$ in the late 1990 s to $3 \%$ during the next decade.

We now turn to a spatial representation at ward level of the three main languages in the metro for the census years 1996, $200 \mathrm{I}$ and 20II. The three colour-coded maps below identify the main household language(s) in each of the III wards of Cape Town (as delineated in 201I). This colourcoding comprises nine categories. In the first place, two shades of the same colour are used for each of the three main languages in order to distinguish between a ward within which one language was selected by more than two thirds of the adult population (dubbed 'predominant' and denoted by the darker shade) and wards where that language was selected by a majority comprising between 50 and $66 \%$ of the adult population (dubbed 'majority' and denoted by the lighter shade). The three remaining categories identify wards in which no language is majoritarian and hence in which the two largest language groups are identified (dubbed 'plurality' and denoted by a mix of the two associated colours). 


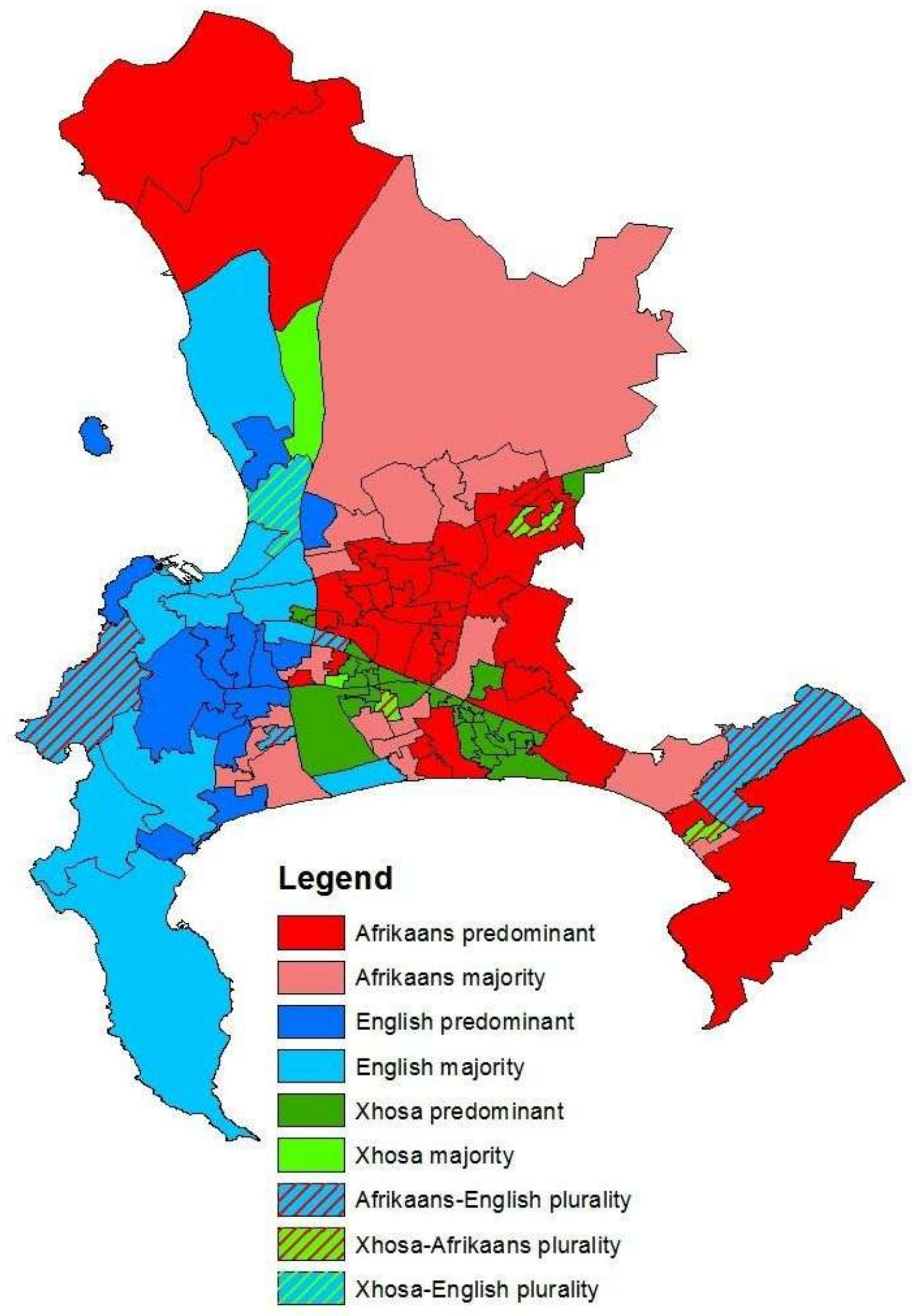

Figure I: Household language by ward, adults in Cape Town (1996) 


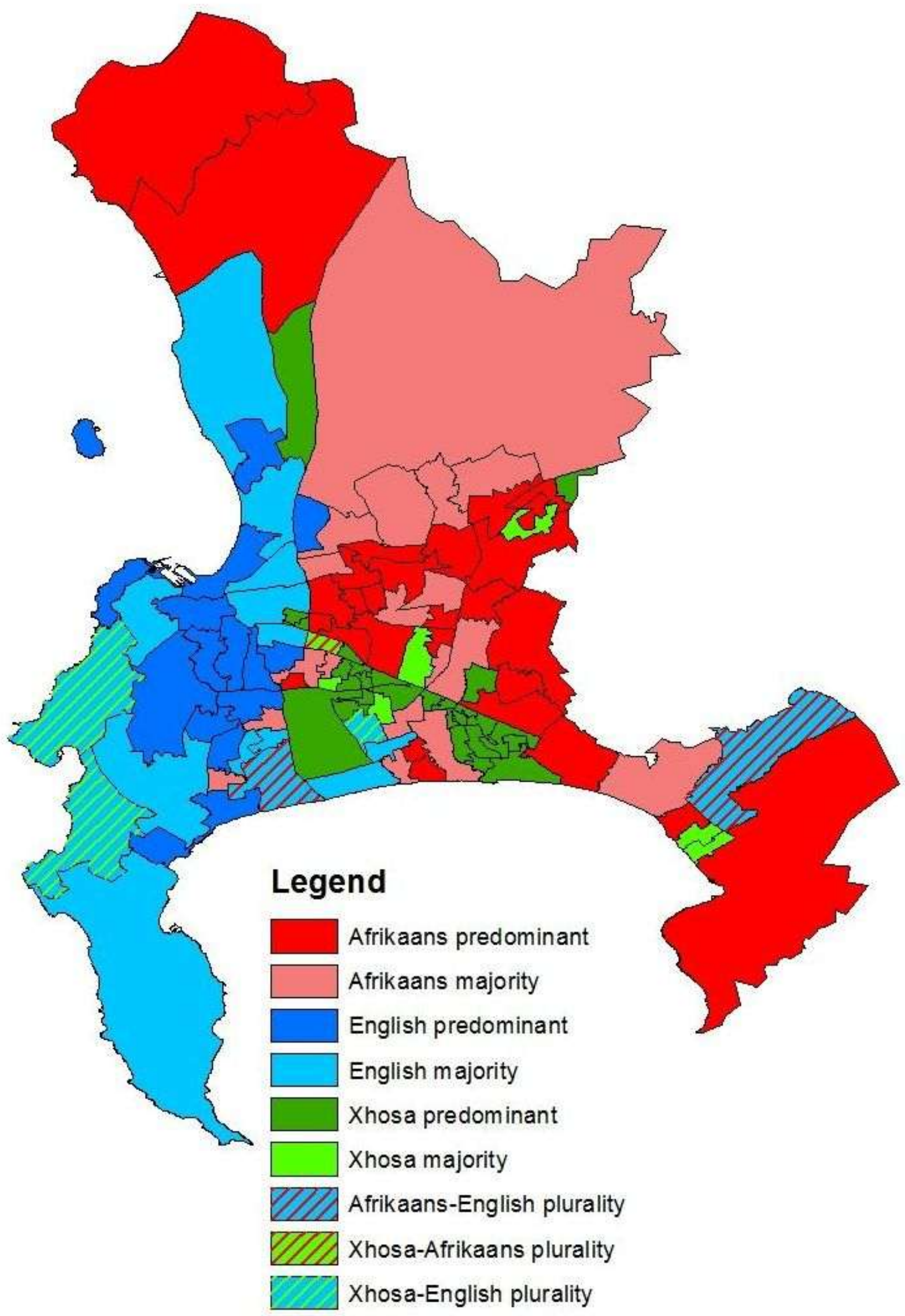

Figure 2: Household language by ward, adults in Cape Town (200I) 


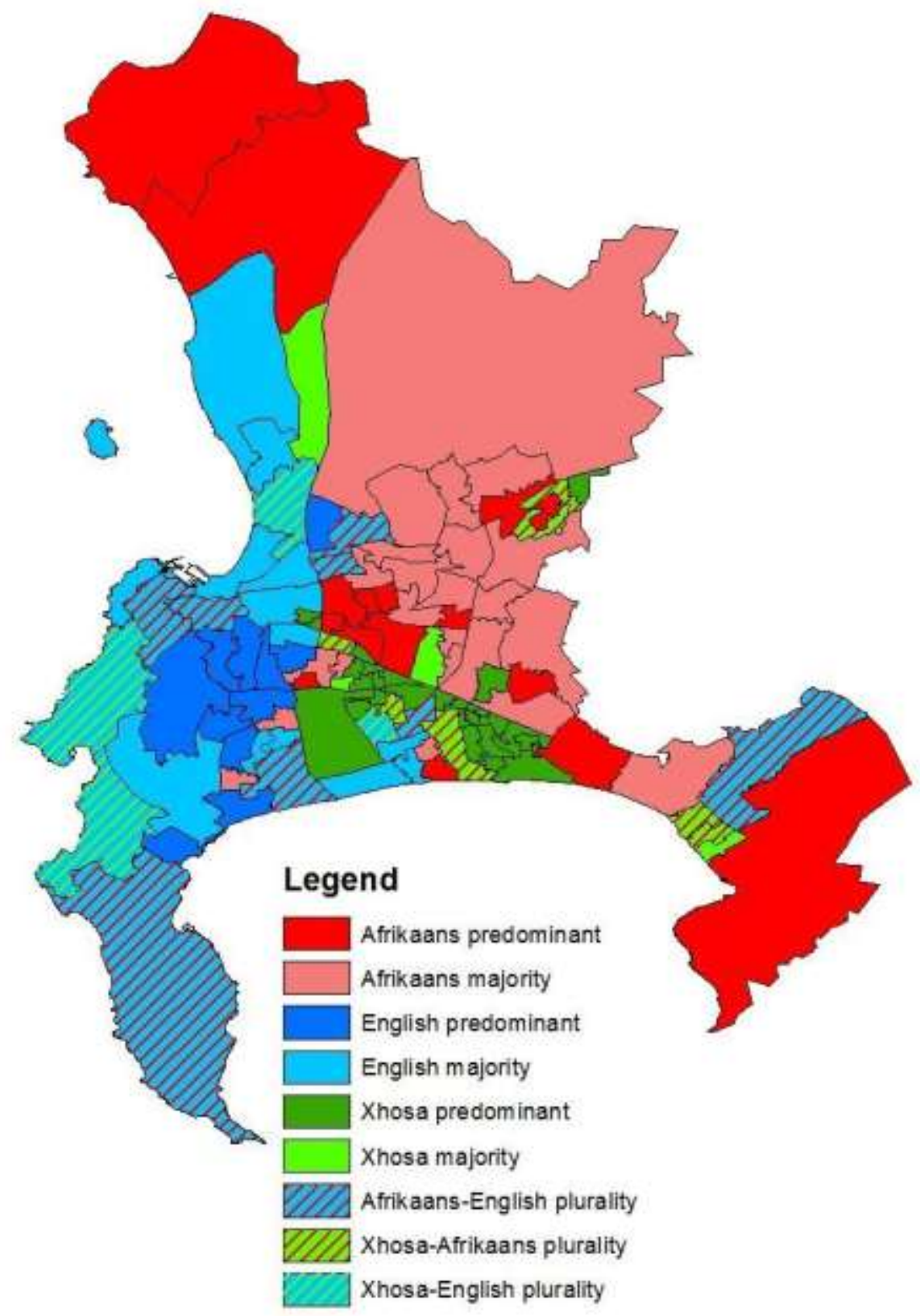

Figure 3: Household language by ward, adults in Cape Town (20 I I)

\section{Principal language trends}

A preliminary analysis of these three maps reveals three broad trends:

Trend I: Over the past fifteen years, Afrikaans has remained the main language in the north-east of the metro. It has maintained predominant status in the northern wards (and Atlantis, in particular) and in a number of the more centrally located wards (in Bonteheuwel, for example). Simultaneously, a number of these centrally sited wards have given up their predominant Afrikaans status for a majoritarian one (in areas such as Bellville) and accordingly join other wards in this sub-metropolitan area which have maintained majoritarian Afrikaans status over this period (such as Welgemoed and Durbanville)

Trend 2: English has maintained its predominant or majoritarian status on much of the peninsula - in the south-west of the metro - despite shedding this status in some peninsula wards (in the vicinity of Simonstown, Noordhoek and Hout Bay). Two other trends regarding English stand out: first, in the peninsula wards commonly referred to as the 'southern suburbs' (from Mowbray to Retreat) English has maintained predominant status; and secondly, in a number of wards in the south of what is commonly known as the 'Cape Flats' (such as Grassy Park and Pelican Park), English has gained 
majoritarian status from previously majoritarian Afrikaans wards.

Trend 3: IsiXhosa has maintained its predominant status in the centre-southern wards of the metro (Langa, Nyanga, Gugulethu and Khayelitsha) whilst showing some spatial migration toward wards on the peninsula and elsewhere. "Xhosa-English plurality" should therefore not be interpreted as 'residential integration', as relatively poor and predominantly African in-migrants tend to reside in dense settlements (such as Masiphumelele on the peninsula) alongside more established and predominantly white residential areas.

Selection of seven Cape Town case studies

Rather than analysing single wards in the metro, we have selected seven case study areas, each being made up by a number of wards sharing the same language patterns over the past fifteen years and comprising contiguous wards (or wards in close proximity of each other).

Two criteria were employed to guide our selection. In the first place, in spatial terms, Cape Town has been depicted as growing lengthwise along two well-performing 'arms' that are described as 'physically integrated': the southern arm overlying the peninsula's Old Main Road, and the Tygerberg eastern arm overlying Voortrekker Road (Watson 2002: 103; also see Turok 2001). Three of the seven case studies fall within the ambit of these arms (cases $1,2,5$ ) and the other four do not (cases $3,4,6,7$ ). Of the latter, three (cases 3,6,7) are located on the 'Cape Flats, in the south-east of the metro. This region houses most of the Cape Town's "disadvantaged communities" (Watson op.cit.). Case study four (Atlantis) is situated in the far north of the metro. In the second place, five of the seven case study areas have been selected because they show no change in language status over the past fifteen years whereas in the other two cases, language status has changed from Afrikaans predominant to majoritarian (case 2) and from Afrikaans majoritarian to English majoritarian (case 6).

We list these case study areas below: the names of two emblematic suburbs falling within each area are used as labels, and the language patterns shared by the wards constituting these areas (during the fifteen year inter-census period $1996-201$ I) are indicated:

Case I: Welgemoed -Durbanville Sustained majoritarian Afrikaans status
Case 2: Bellville-Belhar Shift from predominant to majoritarian Afrikaans status

Case 3: Bonteheuwel-Bishop Lavis Sustained predominant Afrikaans status

Case 4: Atlantis Sustained predominant Afrikaans status

Case 5: Mowbray-Retreat Sustained predominant English status

Case 6: Grassy Park-Pelican Park Shift from majoritarian Afrikaans to majoritarian English status

Case 7: Langa-Khayelitsha Sustained predominant isiXhosa status

Case studies boundaries and ward boundaries within them are shown on Map 4 below.

\section{Class and residential space in Cape Town}

The seven case studies in Cape Town were selected by using criteria relating to the maintenance or shift of main language over the past fifteen years, as well as their ward locations spatially in the metro. In order to categorise each of the seven study areas as higher or lower in terms of socio-economic status (henceforth 'SE status') relative to the SE status of the metro as a whole, we have used two variables to approximate 'class'. We have therefore calculated, for each case study area and for Cape Town as a whole: (I) the proportion of adults reporting postmatric educational qualifications; and (2) the proportion of adults reporting individual incomes exceeding that of R/2800pm in 20II. Four case studies - Bonteheuwel-Belhar, Atlantis, Grassy Park-Pelican Park and Langa-Khayelitsha - fell into the lower socio-economic status range, BellvilleBelhar into the middle range (since its calculated scores were similar to those of the metro as a whole), and two case studies - WelgemoedDurbanville and Mowbray-Retreat - fell into the higher SE range (see Table I).

Having established the relative socio-economic status of each case study area in 2011 , we repeated the process for $200 \mathrm{I}$ and then calculated the intercensus change for each of the class variables. ${ }^{\text {ii }}$ We then compared the case study areas, both in terms of their recent status (20II) and in terms of changes during the inter-census decade of 200I-20II. On the basis of these calculations, three results stand out.

In the first place, within all seven case study areas as well as within the metro as a whole, both SE status indicators have improved. This suggests that a measure of socio-economic amelioration has taken 
place across the board in Cape Town. Secondly, no case study area changed its relative socio-economic status between 1996 and 20II. Thirdly, the case study that revealed the highest improvement was the predominantly English language area of Mowbray-Retreat (where improvements in the post-matric score was $8.8 \%$ and in the income score $3.6 \%$ ) whereas the case study of highest socio-economic status in 2001 and 201I, Welgemoed-Durbanville, revealed equivalent changes of $4.2 \%$ and $1,5 \%$, respectively.

The city as whole revealed improvements of $3.2 \%$ and $1.2 \%$ respectively. Most revealingly

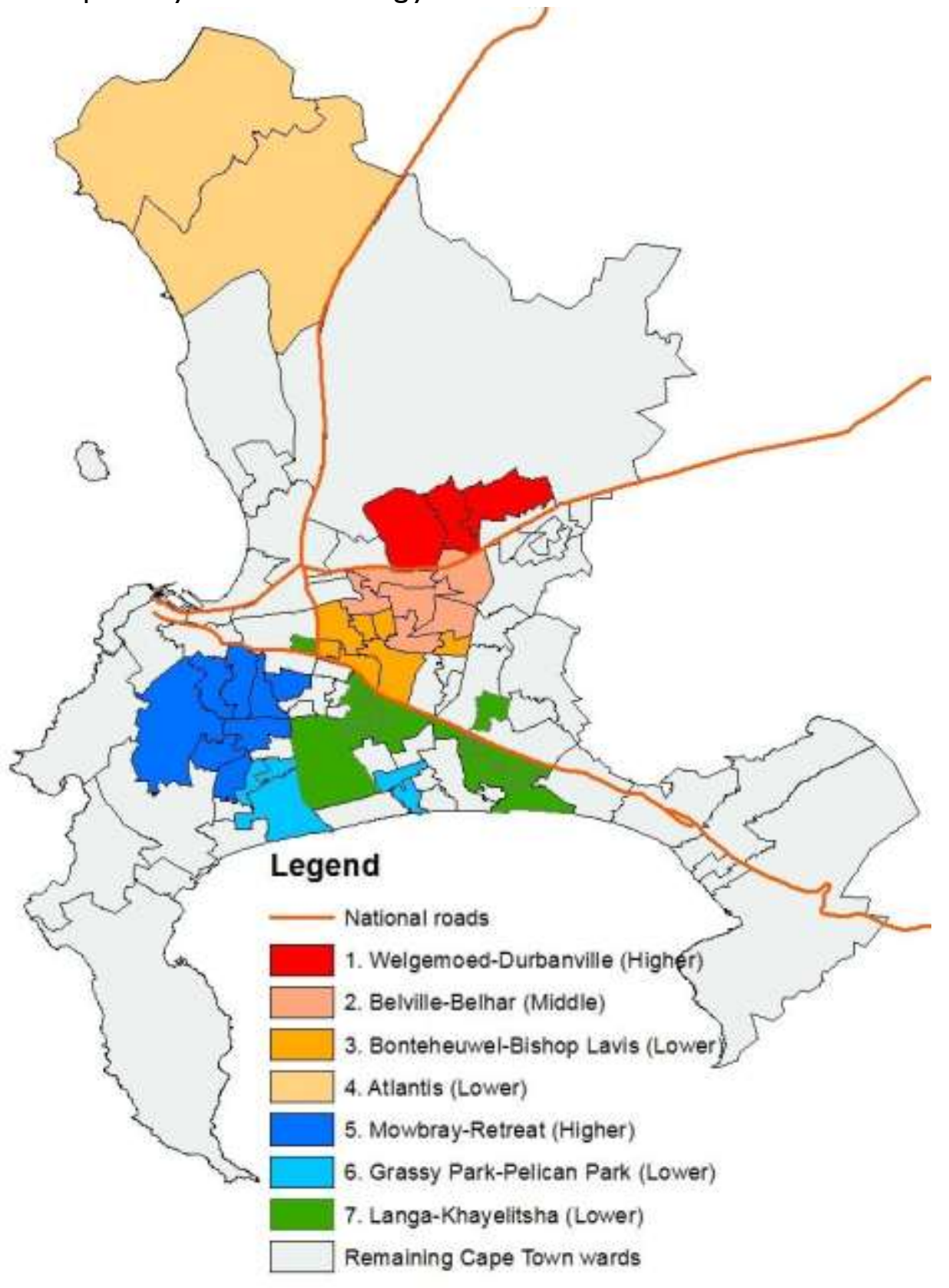

Figure 4: Case study areas: emblematic names and relative socio-economic status 
Table I: Main languages spoken and socio-economic status of the seven sub-metropolitan case studies in Cape Town

\begin{tabular}{|c|c|c|c|c|c|c|c|c|}
\hline CASE STUDIES & $\begin{array}{l}\text { Metro } \\
\text { CAPETOW } \\
N\end{array}$ & $\begin{array}{l}\text { I. Welgemoed- } \\
\text { Durbanville }\end{array}$ & $\begin{array}{l}\text { 2. Bellville - } \\
\text { Belhar }\end{array}$ & $\begin{array}{c}3 . \\
\text { Bonteheuwel - } \\
\text { Bishop Lavis }\end{array}$ & 4. Atlantis & $\begin{array}{l}\text { 5. Mowbray - } \\
\text { Retreat }\end{array}$ & $\begin{array}{l}\text { 6. Grassy Park } \\
\text { - Pelican Park }\end{array}$ & $\begin{array}{l}\text { 7. Langa- } \\
\text { Khayelitsha }\end{array}$ \\
\hline $\begin{array}{c}\text { Language } \\
\text { Shift over I5yrs } \\
\text { I996-20II }\end{array}$ & & $\begin{array}{c}\text { Afrikaans } \\
\text { Majoritarian } \\
\text { No shift }\end{array}$ & $\begin{array}{l}\text { Shift Afrikaans } \\
\text { Predominant to } \\
\text { Afrikaans } \\
\text { Majoritarian }\end{array}$ & $\begin{array}{c}\text { Afrikaans } \\
\text { Predominant } \\
\text { No shift }\end{array}$ & $\begin{array}{c}\text { Afrikaans } \\
\text { Predominan } \\
t \\
\text { No shift }\end{array}$ & $\begin{array}{c}\text { English } \\
\text { Predominant } \\
\text { No shift }\end{array}$ & $\begin{array}{l}\text { Shift Afrikaans } \\
\text { Majoritarian to } \\
\text { English } \\
\text { Majoritarian }\end{array}$ & $\begin{array}{c}\text { isiXhosa } \\
\text { Predominant } \\
\text { No shift }\end{array}$ \\
\hline $\begin{array}{c}20 I \text { I two main } \\
\text { languages spoken } \%\end{array}$ & & $\begin{array}{l}\text { Afr } 62 \% \\
\text { Eng 32\% }\end{array}$ & $\begin{array}{l}\text { Afr } 65 \% \\
\text { Eng 26\% }\end{array}$ & $\begin{array}{l}\text { Afr } 77 \% \\
\text { Eng 19\% }\end{array}$ & $\begin{array}{l}\text { Afr 8I\% } \\
\text { Eng } \\
8 \%(\text { Xh7\%) }\end{array}$ & $\begin{array}{l}\text { Eng } 77 \% \\
\text { Afr I 1 \% }\end{array}$ & $\begin{array}{l}\text { Eng } 50 \% \\
\text { Afr } 41 \%\end{array}$ & $\begin{array}{l}\text { Xho 85\% } \\
\text { Eng } 4 \%(\text { Afr } \\
4 \%)\end{array}$ \\
\hline $\begin{array}{c}1996 \text { two main } \\
\text { languages spoken \% }\end{array}$ & & $\begin{array}{l}\text { Afr } 62 \% \\
\text { Eng } 34 \% \\
\end{array}$ & $\begin{array}{l}\text { Afr } 76 \% \\
\text { Eng 20\% } \\
\end{array}$ & $\begin{array}{l}\text { Afr } 86 \% \\
\text { Eng } 12 \% \\
\end{array}$ & $\begin{array}{r}\text { Afr } 91 \% \\
\text { Eng 6\% } \\
\end{array}$ & $\begin{array}{r}\text { Eng } 81 \% \\
\text { Afr } 14 \% \\
\end{array}$ & $\begin{array}{l}\text { Afr } 54 \% \\
\text { Eng } 44 \% \\
\end{array}$ & $\begin{array}{c}\text { Xho } 93 \% \\
\text { Afr } 4 \%\end{array}$ \\
\hline $\begin{array}{c}\text { Socio-economic } \\
\text { status }\end{array}$ & & Higher & Middle & Lower & Lower & Higher & Lower & Lower \\
\hline $\begin{array}{l}\text { 20II Post matric } \\
\text { Score }\end{array}$ & $15.2 \%$ & $47.9 \%$ & $18.3 \%$ & $4.1 \%$ & $3.6 \%$ & $37.1 \%$ & $6.9 \%$ & $4.7 \%$ \\
\hline $\begin{array}{l}200 \text { I Post matric } \\
\text { Score }\end{array}$ & $12 \%$ & $43.7 \%$ & $16.3 \%$ & $2.5 \%$ & $3.4 \%$ & $28.3 \%$ & $5.0 \%$ & $4.2 \%$ \\
\hline $\begin{array}{l}\text { Improvement Post } \\
\text { matric } \% \\
2001-201 \mathrm{I}\end{array}$ & $3.2 \%$ & $4.2 \%$ & $2.0 \%$ & $1.6 \%$ & $0.2 \%$ & $8.8 \%$ & $1.9 \%$ & $0.5 \%$ \\
\hline $\begin{array}{c}\text { 20II Indiv income } \\
\text { (> RI2 800pm) }\end{array}$ & $10.3 \%$ & $38.4 \%$ & $13.3 \%$ & $2.5 \%$ & $2.7 \%$ & $25.1 \%$ & $4.8 \%$ & $1.1 \%$ \\
\hline $\begin{array}{c}200 \text { I Indiv income } \\
\text { (> R6 400pm) }\end{array}$ & $9.1 \%$ & $36.9 \%$ & $12.1 \%$ & $1.8 \%$ & $1.9 \%$ & $21.5 \%$ & $4.0 \%$ & $0.7 \%$ \\
\hline $\begin{array}{c}\text { Improvement \% } \\
\text { higher income earners } \\
2001-2011\end{array}$ & $1.2 \%$ & $1.5 \%$ & $1.2 \%$ & $0.7 \%$ & $0.8 \%$ & $3.6 \%$ & $0.8 \%$ & $0.4 \%$ \\
\hline
\end{tabular}

Sources: 1996, 200 I, 20 I I SA censuses 


\section{Race and residential space in Cape Town 20II}

A simple albeit broad-brush way to track the extent to which Cape Town has addressed the legacies of the Group Areas Act - the apartheid legislation that defined racially segregated residential areas - is to consider how the racial profiles in our case study areas - based on the four race categories used in the Censuses - have changed over the past fifteen years. In Table 2, ratios have been calculated for adult residents (aged 20+) in the years 1996, 200I and 2011.

Statistics for the city as a whole show that no racial category constituted a majority in $201 \mathrm{l}$. Moreover, while the African proportion has grown over the past fifteen years, coloured and white proportions have decreased. The ratios in the seven case study areas differ from the metro and from each other in the following ways:

- In the first place, five of the seven case study areas reveal a clear majority of residents from one racial category, a majority maintained over the fifteen years.

- In the cases of Bonteheuwel-Bishop Lavis, Atlantis and Grassy Park-Pelican Park, the majority of residents are and have remained coloured. In the case of Langa-Khayelitsha, residents have remained mainly African and in the case of Welgemoed-Durbanville mainly white. All four of the case study areas on the lower end of the socio-economic spectrum have remained largely racially homogenous. By contrast, the case study area with the highest relative socio-economic status - WelgemoedDurbanville - has remained more than $80 \%$ white.

- The two case study areas revealing a substantial mix of residents from different racial categories in 201I are Mowbray-Retreat which was assigned a higher socio-economic status and where no category is majoritarian and BellvilleBelhar which was assigned a middle socioeconomic status and where half of the adult population classified themselves as coloured.

- All case studies except Langa-Khayelitsa display a measure of greater mixing racially taking place over the past fifteen years. In 201 I, MowbrayRetreat appeared to be the most mixed with an adult resident ratio of $13 \%$ African, $43 \%$ coloured, $8 \%$ Indian and $36 \%$ white.
It is worth noting here that middle or higher socio-economic status of case study areas may have become an important context - possibly, precondition - for greater racial residential mixing at ward level (arguably, inter alia, since property prices and hence the possibility to change residence are generally beyond the reach of working class residents). Simultaneously, it is worth noting that such a status is no guarantee of greater residential mixing: the case of Welgemoed-Durbanville reveals this. 
Table 2 Changing racial proportions and in-migration trends of adults in Cape Town's 7 sub-metropolitan case studies

\begin{tabular}{|c|c|c|c|c|c|c|c|c|}
\hline CASE STUDIES & $\begin{array}{c}\text { Metro } \\
\text { CAPE TOWN }\end{array}$ & $\begin{array}{c}I . \\
\text { Welgemoed- } \\
\text { Durbanvill } \\
e \\
\text { higher SE } \\
\text { status } \\
\end{array}$ & $\begin{array}{l}\text { 2. Bellville } \\
- \\
\text { Belhar } \\
\text { middle SE } \\
\text { status }\end{array}$ & $\begin{array}{l}\text { 3. Bonteheuwel - } \\
\text { Bishop Lavis } \\
\text { lower SE status }\end{array}$ & $\begin{array}{c}4 . \\
\text { Atlantis } \\
\text { lower SE } \\
\text { status }\end{array}$ & $\begin{array}{c}5 . \\
\text { Mowbray- } \\
\text { Retreat } \\
\text { higher SE } \\
\text { status }\end{array}$ & $\begin{array}{l}\text { 6. Grassy Park- } \\
\text { Pelican Park } \\
\text { lower SE status }\end{array}$ & $\begin{array}{l}\text { 7. Langa } \\
- \\
\text { Khayelits } \\
\text { ha } \\
\text { lower SE } \\
\text { status }\end{array}$ \\
\hline $\begin{array}{l}\text { Race proportions' } \\
\text { African: Coloured: Indian: } \\
\text { White }\end{array}$ & $\begin{array}{c}\text { ADULTS } \\
20+\end{array}$ & & & & & & & \\
\hline 1996 ratios & $26: 47: 2: 26$ & $2: 10: 0: 88$ & $\begin{array}{l}4: 48: 1: 4 \\
7\end{array}$ & $2: 93: 2: 3$ & $\begin{array}{l}3: 95: 0: \\
2\end{array}$ & $\begin{array}{l}5: 37: 7: 5 \\
1\end{array}$ & 3:93:3:1 & $\begin{array}{l}96: 4: 0: \\
0\end{array}$ \\
\hline 200 I ratios & $31: 45: 2: 22$ & $3: 8: 1: 88$ & $7: 49: 1: 42$ & $4: 91: 2: 3$ & $7: 91: 0: 2$ & $6: 42: 9: 43$ & $4: 91: 2: 3$ & $95: 4: 0: 0$ \\
\hline 2011 ratios & $38: 42: 2: 19$ & $6: 10: 1: 83$ & $\begin{array}{l}16: 50: 2: 3 \\
2\end{array}$ & $6: 91: 2: 2$ & $\begin{array}{l}\text { 13:86:0: } \\
1\end{array}$ & $\begin{array}{l}13: 43: 8: 3 \\
6\end{array}$ & $12: 85: 2: 0$ & $96: 4: 0: 0$ \\
\hline $\begin{array}{l}\text { In-migration over the decade } \\
2001-201 \mathrm{I} \\
\text { Adults }(30+\text { in } 201 \mathrm{I})\end{array}$ & $\begin{array}{c}\text { ADULTS } \\
30+\end{array}$ & & & & & & & \\
\hline $\begin{array}{c}\text { In-migration rates } \\
\text { into Cape Town: } \\
\% \text { total population } 30+\end{array}$ & $29 \%$ & $44 \%$ & $29 \%$ & $13 \%$ & $13 \%$ & $32 \%$ & $21 \%$ & $23 \%$ \\
\hline $\begin{array}{c}\text { From foreign sending areas, by } \\
\text { race } \\
\text { (\% above City average) }\end{array}$ & Cross-border & $\begin{array}{c}\text { Afr: } \\
\text { higher } \\
\text { wh: > } \\
\text { double }\end{array}$ & & & & $\begin{array}{c}\text { Afr: } \\
\text { higher } \\
\text { wh: } \\
\text { higher }\end{array}$ & Afr: higher & \\
\hline $\begin{array}{c}\text { From Eastern Cape } \\
\text { (\% above City average) }\end{array}$ & Inter-provincial & & col: higher & & $\begin{array}{l}\text { col: } \\
\text { higher }\end{array}$ & & & $\begin{array}{c}\text { Afr: > } \\
\text { double }\end{array}$ \\
\hline $\begin{array}{c}\text { From other SA provinces, by race } \\
\text { (\% above City average) }\end{array}$ & Inter-provincial & $\begin{array}{l}\text { Ind: higher } \\
\text { wh: }> \\
\text { double }\end{array}$ & & & & $\begin{array}{l}\text { col: higher } \\
\text { Ind: higher } \\
\text { wh: higher }\end{array}$ & & Afr: higher \\
\hline $\begin{array}{l}\text { From Western Cape- } \\
\text { Cape Town included } \\
\text { (\% above City average) }\end{array}$ & $\begin{array}{l}\text { Intra-provincial } \\
\text { and metro }\end{array}$ & $\begin{array}{l}\text { wh: }> \\
\text { double }\end{array}$ & $\begin{array}{l}\text { col: higher } \\
\text { wh: higher }\end{array}$ & col: higher & & $\begin{array}{l}\text { col: higher } \\
\text { Ind: }> \\
\text { double } \\
\text { wh: higher }\end{array}$ & col: higher & $\begin{array}{l}\text { Afr: }> \\
\text { double }\end{array}$ \\
\hline
\end{tabular}

\section{Sources: I 996, 200 I, 20 I I SA censuses}

\footnotetext{
1 'Unspecified’ responses excluded.
} 


\section{Migration trends in the case study areas}

In order to provide a broad overview of migration into Cape Town and the seven sub-metropolitan case studies areas identified above, we explore migration trends at two junctures. We begin by summarising the migration trends established by researchers a decade ago - little primary research has been done since (Bekker 200I, Bekker 2002, Bekker \& Cramer 2003, Cross and Bekker 1999, Marindo et al. 2008). We then use $201 \mathrm{I}$ census data (presented in Table 2) to assess the extent to which these earlier trends have changed or persisted.

In 200I the net flow of migrants into Cape Town was positive. When disaggregated in terms of race, however, it was evident that African and white inflows were high, whereas there was probably a small but significant outflow of coloured residents particularly toward Gauteng (Cross \& Bekker 1999: 73). The high level of intra-metropolitan mobility at this time was reported as follows:

$(\mathrm{H})$ ousehold mobility differs significantly by race and type of settlement. ..Movement through the (metro) housing market is still highly segmented by race. The coloured, white and black populations appear to move in different areas for the most part, and by different processes. Whites were well provided for, but the black and coloured populations are effectively unable to move up to a position of advantage in regard to housing and physical provision... For the coloured grouping, the rental market seems to absorb most of (those in the migration stream)... For the black population, the informal areas offered abundant space (for them)... (Cross \& Bekker 1999: 93).

A number of other trends were evident by $200 \mathrm{I}$ :

- The number of African migrants moving to the metro was high, when compared with 1980s. In the context of an urban transition - to the extent that in-migrants hailing from rural areas and small towns were settling in their city of choice - Cape Town was reported to be receiving migrant flows from the Eastern Cape that were considered to be "gravity flows", rather than "circulatory flows". Among IsiXhosa-speakers in particular, it was noted that while many yearned to return to their ancestral homes, most tended to remain in Cape Town (Bekker 200I).

- The number of coloured migrants moving to Cape Town had diminished from a high point in the 1970s and 1980s. In 200 I residents in this racial category represented the most stable sub-population, and were described as Cape Town's 'demographic anchor' (Cross \& Bekker 1999: 15). Mobility at this time was overwhelmingly intra-metropolitan. While coloured urbanization in the Northern and Western Cape continued, provincial towns had largely replaced the metro as the primary receiving area. (Bekker \& Cramer 2003).

- White migrants were largely an 'elite group' and tended to be very mobile, moving not only within but also into and out of the metro. During the late 1990s substantial in-migration streams tended to comprise older adults in small households bringing substantial resources (Cross \& Bekker 1999).

- The fourth category to consider here is that of foreigners. Their presence in Cape Town a decade ago was minor, although it was considered to be worth mentioning (Bekker 2002: 33f).

In turning our attention to more recent trends, we focus solely on adult migration streams during the census decade of 200I-20II. Here adult residents in Cape Town have been defined as those who were at least 20 in 2001 . Using 201 I census data, the 'adult population' was consequently restricted to people 30 years or older. Our analysis was limited by two constraints: firstly, we were unable to cross-tabulate the migration and language variables, as these are housed in discrete 'cubes' in the original release of the $201 \mathrm{I}$ data; and secondly, we were unable to explore mobility within the metro, as the relevant variables were not available. We have consequently looked at migration between the metro and other regions. Inter-provincial and cross-border data have been assembled and analysed in terms of provincial and foreign origin, as well as race (see summary in Table 2 below). These data simply indicate, for sub-metropolitan case studies, where in-migration streams (calculated as the proportion of adults aged $30+$ in the area under consideration who reported having changed residence during the past decade) are 'higher' than the metro average and, in the case of very large increases, are more than double this average ('> double').

In the 20II Census almost three adults out of ten in Cape Town reported having made at least one 
residential move during the past decade. This high adult mobility points to both the likelihood that the metro retained its positive net migration status as well as high intra-metropolitan mobility: interprovincial flows in 1996 and 2011 show clear net migration into the Western Cape (Marindo et al. 2008: 12; census 20II); and a high proportion $(72 \%)$ of all moves that took place were within the Western Cape (and probably largely within the metro).

- In-migration flows of adult isiXhosa-speakers ${ }^{\text {xii }}$ have remained higher than for other language groups and higher than the metro average but have dropped significantly below annualized flows in the late 1990s, as reported above.

- Adult coloured residents in the metro appear to have retained their status of 'demographic anchor': some $95 \%$ are born in the Western Cape, the large majority in Cape Town in all probability (census 20II).

- White residents also appear to have retained their high mobility. This grouping revealed by far the highest proportion of adult residential moves: more than four adult respondents out of ten reported a change of residence (whereas the proportion dropped to three out of ten for African adults and less than two out of ten for coloured adults) (census 20II).

- Indian migration streams into the metro have been small in comparison with other racial categories. Rates however have been picking up over the past decade and the two most significant sending areas are KwaZulu-Natal and foreign countries.

- Foreign migrants entering Cape Town appear to have become an increasingly visible and influential sub-population: some one in ten adults migrating into Cape Town over the past decade reported a foreign country as their sending area, of whom approximately twothirds hailed from Africa and one third from other continents (census 20I I)

We now focus on adult migration into our seven sub-metropolitan case study areas during the last inter-census decade (see Table 2).

- In the first place, regarding isiXhosa-speaking African migration, it appears that most adults hailing from the Eastern Cape as well as those changing residence within the metro settle in, or switch residence within, the Langa-
Khayelitsha case study area. Most foreign African adult migrants however appear to prefer to settle in the higher socio-economic status areas of Welgemoed-Durbanville and Mowbray-Retreat. A substantial grouping of the latter has also taken up residence in Grassy Park-Pelican Park, and this may also help to explain the growing number of people using English in this area.

- Large numbers of coloured adults on the move within the metro appear to have settled in the three study areas of Bellville-Belhar, Bonteheuwel-Bishop Lavis and Grassy ParkPelican Park as well as in the predominantly English-language area of Mowbray-Retreat. The Atlantis case study emerges as an exception with low overall in-migration and comparatively fewer migrants from the metro itself. This may be due to its peripheral spatial location within the metro.

- The two case study areas with higher relative SE status show high levels of white in-migration, but this is particularly evident in the Welgemoed-Durbanville case. This holds true for white adults from all South African provinces as well as from abroad.

While overall adult migration into and within Cape Town is high at $29 \%$, it is noteworthy that migration to the seven case study areas correlates with their relative SE status: the two higher SE areas have the highest in-migration rates; the middle SE status Bellville-Belhar area has an in-migration rate equivalent to that of the metro; and the four lower SE status areas all have in-migration levels lower than the metro, with Bonteheuvel-Bishop Lavis and Atlantis the lowest rate at 13\% (Table 2). It would therefore seem that geographical mobility (migration) and upward social mobility are linked, with the latter tending to facilitate the former. Adult migrants with resources and a wider range of residential options, tend to select higher SE areas. On the other hand, adults in the lower SE case study areas are constrained by income and other material considerations. ${ }^{\text {iv }}$ But language resources also need to be considered.

\section{Conclusion}

We conclude this article by exploring broad patterns of continuity and change with respect to language and inequality in Cape Town. We revisit the questions posed in the introduction, regarding the 
extent to which class and racial divisions within Cape Town's residential space have changed. Subsequently, since the current sustained geographical clustering of speakers of the three main languages in the metro has a complex history of settlement and migration, we sketch a brief historical background to their establishment in the metro over the past 200 years before turning to an exploration of the extent to which these languages correlate with the spatial reproduction of racial and class inequality.

Our analysis of census data on class, race and residential space in the metro points to little more than partial success in Cape Town's attempt to overcome racial segregation and entrenched class inequality in residential areas. Trends regarding desegregation vary in the different case study areas analysed above, but overall this is occurring within a class matrix that has changed little since 1996. Of the seven case study areas, only two can be described as racially mixed to a significant degree: Mowbray-Retreat and Bellville-Belhar. The significance of these two areas is that they straddle the two main developmental axes (elaborated below) in Cape Town. It is noteworthy that the two case studies with the highest relative social status (Mowbray-Retreat and Welgemoed-Durbanville) both have high levels of in-migration. In the case of Welgemoed-Durbanville however, in-migrants are predominantly white.

The four selected lower SE status areas have remained overwhelmingly racially homogenous coloured and African - over the past fifteen years. In addition, the data suggest that these areas fared the worst comparatively regarding both socio-economic as well as spatial mobility: relative both to the metro and the other case study areas, all four scored lower improvements in our proxies for class mobility and attracted fewer adult migrants over the past decade.

Overall then, while broad class patterns remain, it does not appear that racial segregation is being replaced by class segregation in the metro area as a whole. As social constructs go, 'class' is notoriously difficult to conceptualize and measure. Our operationalization of class in terms of the census variables "monthly income" and "level of education", is useful as a broad approximation. It is however necessary to add to this analysis a discussion of other factors associated with social stratification - not least of which is language.
While language has been instrumental in the construction of social divisions in Cape Town since the beginning of colonial occupation, we would trace the broad language patterns described above to the post 1805 British occupation of the Cape. The predominance of white English speakers in the suburbs to the south of the 'city bowl' can be traced to the in-migration of British settlers in the nineteenth century. Thus, by the middle of the nineteenth century...

"...Cape Town had become an identifiably British colonial city. English was generally accepted as the medium for public discourse. In government, business, school and even church the British dominated" (Worden et al.: 153).

Education played a particularly significant role in establishing English and 'the English' in positions of social dominance. It is no coincidence that the "Mowbray-Retreat" case study area - discussed above - includes many highly prestigious public and private schools. The association of English with advanced education in elite institutions can be traced back to the establishment of the first public schools in this area and the subsequent development of a colony-wide system of higher education (Hill, 2008).

During the nineteenth century English was therefore the exclusive medium of advanced education. As such, it did not simply 'exist' alongside 'Dutch'. English - or rather first and second language English speakers - formed part of a process of social stratification, which by the end of the nineteenth century had produced a stratified Dutch creole continuum. At the beginning of the twentieth century 'Cape Dutch' and the associated written standard had diverged considerably from the 'white' and 'coloured' vernaculars that would subsequently be subsumed under the label of 'Afrikaans.' The standardization of 'white Afrikaans' during the first half of the twentieth century was the linguistic project of Afrikaner nationalism. In Cape Town white Afrikaans communities developed along the second major axis of urban expansion to the east of the city bowl. By the middle of the twentieth century municipalities were established for Goodwood, Parow and Bellville. Economic and manpower requirements during the Second World War attracted large streams of migrants. At this time,

"the white populations (of these suburbs) became predominantly Afrikaans-speaking.... Tygerberg Hospital, linked to Stellenbosch 
University, was the first to teach medicine and dentistry in Afrikaans. The Afrikaner financial giant Sanlam moved its headquarters to Bellville in 1962, initiating numerous commercial ventures. In 197I the opening of Parow's Sanlam shopping centre symbolised the contemporary strength of Afrikaner capitalism..." (BickfordSmith et al: 186)

The two 'arms' of development referred to earlier - the southern arm extending along Main Road and the eastern arm overlying Voortrekker Road - are historically associated with two distinct language-influenced patterns of settlement, socioeconomic development and residential inclusion and exclusion.

With respect to the Voortrekker Road axis, this pattern has been complicated by the in-migration of coloured Afrikaans speakers. The urbanization of coloured residents in the Western and Northern Cape has taken place in two waves, both step-wise rather than direct (toward the metro). Until the early 1990s, urbanization streams from rural areas, mission stations and small towns where residents were overwhelmingly Afrikaans-speaking, were directed initially toward regional towns and eventually toward Cape Town. These streams toward the metro were probably at their peak in the 1970s and 1980s, the decades when the Cape Town city council laid out and established the townships of Atlantis, Mitchell's Plain and Blue Downs (BickfordSmith et al.:206,207). The second more recent wave constitutes a continuation of this step-wise migration toward regional towns but on-migration to Cape Town appears to have diminished radically as streams of isiXhosa-speaking migrants began to settle in the metro (Bekker and Cramer 2003).

Finally, the dense concentration of isiXhosa speakers in the coastal region largely south of the coastal national road (N2) is a particularly noteworthy pattern of continuity over the fifteen year period in question. The residential location of most isiXhosa speakers in areas far from the two main developmental axes is evidence of their relatively recent in-migration and their political and cultural exclusion. The urbanization of African residents began with small streams (into Naledi and later into the new 'location' of Langa) in the first half of the 20th century. During the apartheid years African in-migration was constrained as a result of the coloured labour preference policy. Notwithstanding this policy, in-migration into informal settlements - such as Crossroads continued to grow. During the 1980s the national government established the township of Khayelitsha - between the N2 and False Bay - thereby bringing its coloured labour preference policy to a close. An immediate consequence was the rapid and remarkable increase in the number of isiXhosaspeakers hailing from the Eastern Cape (and from the Transkei in particular).

It is apparent then that the metro's three main languages are associated with different streams of migrants settling in different zones of the city at different times and for different reasons. The language policies and practices at the level of the national state, the province and the city - as well as of the private sector - have defined in large measure the influences these languages have had on the life chances and living conditions of residents in the city. Language policies in primary, secondary and tertiary educational domains, language expectations at the work place, and languages employed in the mass media are contexts in which the relative status of languages differ. In our final discussion of the case study areas, our analysis of the relative status of English, Afrikaans and isiXhosa therefore draws on both functional and spatial contexts, where the latter refers specifically to relative proximity to the city bowl and its two development 'arms.' Accordingly, as we explore whether a language may be playing a facilitating or inhibiting role in class, racial and migration shifts taking place in our seven case study areas, we need to keep in mind that there are other factors that contribute to facilitation or to inhibition.

Afrikaans emerged in 201I as the main household language of residents in four of the case studies: Welgemoed-Durbanville, Bellville-Belhar, Bonteheuwel-Bishop Lavis and Atlantis. Since these include areas of high, middle and low SE status and differing relative streams of in-migrants, it is apparent that Afrikaans on its own cannot be considered to influence mobility in either a facilitating or inhibiting fashion. What is more likely is that it does tend toward one of these two options when considered together with other factors:

- Welgemoed-Durbanville and Bellville-Belhar though majoritarian Afrikaans display large minorities of English-speakers in their area and relatively high in-migration from both the metro and foreign countries. They are also within the embrace of the Voortrekker development arm and accommodate established schools that 
offer education in both Afrikaans and English. Afrikaans and English clearly facilitate upward class mobility in these areas, but in the Welgemoed-Durbanville, English and Afrikaans (and English-Afrikaans bilingualism) also seem to facilitate racial homogeneity.

- Bonteheuwel-Bishop Lavis and Atlantis, on the other hand, have remained predominantly Afrikaans over the last 15 years (more than 3 out of 4 adult residents in both cases). They also display low in-migration streams and are distant from the educational and formal employment institutions embraced by the city bowl and its development arms. In these cases, Afrikaans would appear to sustain both racial and working class segregation.

The two remaining case studies, MowbrayRetreat and Grassy Park-Pelican Park, were both classified as mainly English-speaking in $201 \mathrm{I}$.

- The first case of the 'southern suburbs' has already been described as (i) the most racially mixed, (ii) the most rapidly upwardly mobile, (iii) with high in-migration streams and (iv) remaining predominantly English-speaking (more than 3 out of 4 adults) over the past fifteen years. Given that these suburbs are situated on the southern development arm of the metro, English clearly plays a pivotal role in facilitating both social and geographical mobility.

- The second case, Grassy Park-Pelican Park, is our only example of language shift from Afrikaans to English. Most of the suburbs within this area are close to the macro AfrikaansEnglish language divide in the metro and it is plausible to hypothesize that bilingualism is common in these residential areas. Accordingly, since this case study area is of low SE status and characterised by high racial homogeneity and little upward mobility, it appears that English is less obviously a facilitator of development.

In the case of Langa-Khayelitsha, for a number of interrelated factors, isiXhosa as the predominant language is associated with racial and class segregation: this language has limited status as a medium of instruction in schools; it is rarely needed at formal work places and is not widely known among Capetonians who speak Afrikaans or English. The residential areas themselves are far from the city bowl and the development 'arms' of the metro, and most isiXhosa-speaking migrants entering or migrating within the metro have little choice of settlement outside this case study area.

In conclusion, we have presented a spatial analysis of the relationship between 'household language' and patterns of inequality based on race and socio-economic status. 'Household language' is a broad and somewhat blunt concept; our use of census data therefore restricts our ability to say more about the language repertoires of Cape Town residents. Bilingualism and code-switching, in particular, are issues that we were not able to explore in our analysis of the case study areas. Significant levels of English-Afrikaans and EnglishXhosa bilingualism in Cape Town is a reasonable inference that can be drawn from the 201I Census figures for the Western Cape. ${ }^{\mathrm{xv}}$ To the extent that this is true, it would suggest an increasingly important future role for English as a lingua franca in the city. But based on our analysis of ward-based language profiles, it seems clear that both English and Afrikaans remain firmly established in integrated but discernible sub-regions of the metro.

While English and Afrikaans currently share official status with isiXhosa, their de facto status can be traced back to the settlement practices and language policies of the Cape Colony and the post1910 South African state. Their continued status in the city can be explained by the manner in which they are inscribed in urban social space. Geography is one aspect of this space, and our analysis has focused particular attention on two development corridors in Cape Town. Our analysis of selected case study areas shows that the broad trend with respect to the metro-wide status of English and Afrikaans needs to be qualified in terms of location relative to these two corridors. Thus, while Afrikaans is clearly associated with relative wealth and upward social mobility in the WelgemoedDurbanville and Bellville-Belhar areas, the same cannot be said for Bonteheuwel-Bishop Lavis and Atlantis. By contrast, isiXhosa speakers living in the Langa-Khayelitsha case study area are doubly marginalized: by the relatively low-social status of their language and by their location in historically marginalized areas of the city. The continued concentration of isiXhosa speakers in these areas does not bode well for the City's stated intention to address the inequalities inherited from the past and to facilitate the desegregation of residential areas. And while the allocation of resources and services to historically marginalized areas will continue be the subject of contention, our analysis also suggests that 
proximity to the two axes of socio-economic development is an underestimated dimension of inequality in Cape Town. ${ }^{\text {xvi }}$

\section{References}

Anthonissen, C. 2013. "With English the World is more open to you'- language shift as a marker of social transformation" English Today 29, (I): 2835.

Bekker, S. 200I. "Diminishing returns: Circulatory migration linking Cape Town to the Eastern Cape" South African Journal of Demography 8, (I): I-8.

Bekker, S. 2002. Migration Study in the Western Cape. Report for the Provincial Government of the Western Cape: Cape Town.

Bekker, S. and Cramer, J. 2003. "Coloured migration in the Cape region at the beginning of the $21^{\text {st }}$ century" Acta Academica Supplementum I: Spatialities of South African urban change: perspectives on post-apartheid urban problems and challenges at the beginning of the twentyfirst century, pp I05-I29.

Bekker, S. and Leildé, A. 2006. "Class, race and language in Cape Town and Johannesburg" pp 145-170. In Reflections on Identity in Four African Cities, edited by S. Bekker and A. Leildé. Cape Town, African Minds.

Bickford-Smith, V. 1995. Ethnic pride and racial prejudice in Victorian Cape Town. Cambridge: Cambridge Univ Press.

Bickford-Smith,V., van Heyningen, E. and Worden, N. 1999. Cape Town in the twentieth century. Cape Town: David Philip.

Boughey, C. 1998. "Language and 'disadvantage' in South African institutions of higher education: implications of critical challenges to second language acquisition discourses for academic development practitioners" South African Journal of Higher Education 12: 166- 173.

Bourdieu, P. 199I. Language and symbolic power. Cambridge: Polity Press.

Cameron, R. 2010. "Criteria for determining municipal boundaries and categorization of metropolitan municipalities" Report prepared for the Municipal Demarcation Board.

Craythorne, D.L. 2003. Municipal Administration The Handbook. Cape Town: Juta.

Cross, C. and Bekker, S. 1999. "En waarheen nou? Migration and settlement in the Cape Metropolitan Area" Occasional Paper 6,
Department of Sociology, University of Stellenbosch.

Donnelly, S. 2003. "Language and the census" allAfrica.com.

Dubow, S. 2006. A Commonwealth of Knowledge: Science, sensibility and White South Africa 18202000. Oxford: Oxford University Press.

Farmer, J.L. and Anthonissen, C. 20I0. "Transitions and translations from Afrikaans to English in schools in the Helderberg area" Stellenbosch Papers in Linguistics 39: I-23.

Fishman, J.A. 1967. "Bilingualism With and Without Diglossia; Diglossia With and Without Bilingualism". Journal of Social Issues 23: 29-38.

Giliomee, H. 2003. The Afrikaners: biography of a people. Cape Town: Tafelberg Publishers.

Granville, S; Janks, H; Mphahlele, M; Reed, Y; Watson, P; Joseph, M \& Ramani, E. 1998. "English With or Without G(u)ilt: A Position Paper on Language in Education Policy for South Africa" Language and Education, 12, (4): 254272.

Hill, L. 2008. Language and higher education in South Africa. PhD thesis, University of Warwick.

Keegan, T. 1996. Colonial South Africa and the origins of the racial order. Cape Town: David Philip.

Leildé, A. 2008. Changing identities in urban South Africa: an interpretation of narratives in Cape Town. PhD thesis, University of Stellenbosch.

Marindo, R.; Groenewald, C. and Gaisie, S. (eds.) 2008. The state of the population in the Western Cape. Cape Town: HSRC Press.

Oldfield, S. 2004. "Urban networks, community organising and race: an analysis of racial integration in a desegregated South African neighbourhood" Geoforum 35, (2): I89-20।.

Saff, G. 1998. Changing Cape Town: urban dynamics, policy and planning during the political transition in South Africa. Lanham: University Press of America.

Setati, M.; Adler, J.; Reed, Y. and Bapoo, A. 2002. "Incomplete Journeys: Code-switching and Other Language Practices in Mathematics, Science and English Language Classrooms in South Africa" Language and Education 16, (2): I28-149.

Smith, D. M. (ed) 1992. The Apartheid City and Beyond. Urbanization and Social Change in South Africa. Johannesburg: Witwatersrand University Press. 
Vol. 28, No. I: Suppl on Population Issues in South Africa, May, 2014

Turok, I. 200I. "Persistent Polarisation PostApartheid? Progress towards Urban Integration in Cape Town" Urban Studies 38, (13): 23492377.

Watson, V. 2002. Change and continuity in spatial planning: metropolitan planning in Cape Town under political transition. London: Routledge.

Wilkinson, P. 2000. "City profile. Cape Town" Cities 17, (3): 195-205.

Worden, N. Van Heyningen, E. and Bickford-Smith, V. 1998. Cape Town: the making of a city. Cape Town: David Philip.

\footnotetext{
'The census data released in 2012 (SuperCROSS) contains just one variable on language, representing 'first language' or rather the first coded response to the question on language.

ii In the 2011 questionnaire the two language response categories are not clearly ordered, but in the released data they are labelled "first" and "second".

iii For an influential early treatment of the distinction between psycholinguistic and sociological notions of bilingualism, see Fishman (1967). With respect to the 2011 South African census, this ambiguity in the language question was noted by Tom Moultrie at a UCT seminar titled "NONCONCENSUS? Problematic aspects associated with the 2011 SA Census", 21 February 2013.

iv These figures are based on a province-based cross-tabulation of the two language variables, received from Stats SA. As the second language variable does not form part of the initial SuperCROSS data set, we are not able to provide a corresponding figure for the City of Cape Town.

$\checkmark$ We prefer the term 'race' over the official census use of 'population group', because the former connotes both 'racial categories' and the critical discourse that focuses on the use of these categories. While we acknowledge debate on the appropriateness of using official racial nomenclature, our usage reflects current legal conventions and post-1994 policies aimed at redressing the legacies of racial discrimination. The categories used in the 2011 South African census are: Black African; Coloured; Indian or Asian; White; and Other.

vi Email correspondence with researchers at Stats SA.

vii We are indebted to Gerbrand Mans, of Council for Scientific and Industrial Research (CSIR, in Stellenbosch), for assistance with the preparation of the data used in this paper.

viii These languages are officially recognised by the Western Cape Province.

ix Here 'in-migration' covers migration to Cape Town from other provinces and from outside South Africa. The provinces included the Western Cape, but at the time of publication, we were unable to obtain access to a variable that would allow us to distinguish intra-city migration and in-migration from the Western Cape.

${ }^{x}$ This census variable reflects reported individual incomes and does not include other forms of individual wealth, notably in the form of property or equities.

${ }^{x i}$ Census responses that were classified as 'not applicable' in 1996, 2001 and 2011 have been excluded from these calculations.

xii Annualised South African CPI inflation rates for the inter-census decade $2001-2011$ were used to calculate a 2001 individual monthly income equal in real terms to R12 800pm in 2011. The result was R6400-pm. The income indicators therefore reflect the difference between the proportion of people (in the ward, area or city) that earned more than R12800pm (in 2011) and R6400 (in 2001).
}

xiii This is inferred from the number of African in-migrants (the overwhelming majority of whom are isiXhosa speakers from the Eastern Cape). In the Census 2011 data set (SuperCROSS) that we received, the migration and language variables are situated in different "cubes", and therefore cannot be cross-tabulated.

xiv If the volume of state-subsidised housing (for qualifying households) built over the past decade is factored into this discussion - housing largely falling within lower SE areas - the result of higher mobility in higher SE status areas is even more telling.

${ }^{x v}$ At provincial level $71 \%$ of English selected Afrikaans as the second household language, while the corresponding figure for Afrikaans-English was $70 \%$. About $62 \%$ of isiXhosa speakers selected English as the second language. Just over $5 \%$ of isiXhosa speakers selected Afrikaans as the second language.

xvi Both authors listed above confirm that they have contributed sufficiently to the work submitted and that the content of the manuscript has never been previously been published. 